\title{
AL-ITTIHAD DALAM TASAWUF
}

\author{
Oleh: \\ Rahmi Damis \\ Dosen Aqidah Filsafat Islam \\ Fakultas Ushuluddin, Filsafat \& Politik \\ UIN Alauddin Makassar
}

\begin{abstract}
Abstrak
Salah satu ajaran tasawuf adalah al-Ittihad yang dibawa oleh Abu Yazid Thaifur bin 'Isa bin Surusyan al-Bustami. Al-Ittihad mengajarkan persatuan antara Tuhan dengan hamba yang sudah mencapai kesucian, sehingga seorang sufi yang berada pada tingkat al-Ittihad merasa dirinya bersatu dengan tuhan, satu tingkatan yang menunjukkan bahwa yang mencintai dan yang dicintai telah menjadi satu, sehinggga salah satu dari mereka dapat memanggil yang satu lagi dengan katakata, "Hai aku. Al-Ittihad dicapai dengan melalui fana dan baqa. Fana merupakan hancurnya perasaan kesadaran akan adanya tubuh kasar manusia, yang tersisa adalah manusia secara rohani. Untuk itu sebelum memasuki tahap fana seorang sufi harus memperhatikan 4 hal yaitu; Al-Sukr yaitu keadaan antara cinta dengan fana. Al-Syathahat adalah ungkapan-ungkapan aneh yang dikeluarkan oleh sufi. Zawal al-Hujab adalah keadaan sufi yang tidak menginginkan lagi sesuati kecuali Allah. Ghalbat al-Syhud; keadaan seorang sufi baik dari segi perasaan, kesadaran dan penyaksian sampai kepada puncak fana', lalu dia lupa dirinya dan tidak ada selain Allah.
\end{abstract}

\section{Keywords:}

Tasawuf, al-Ittihad, Penyatuan

\section{PENDAHULUAN}

Manusia sebagai makhluk Tuhan yang mempunyai unsur jasmani dan rohani, saling membutuhkan antara satu dengan yang lain da, jasmani dapat bergerak apabila disertai dengan gerak rohani, demikian pula sebaliknya rohani tidak dapat terwujud tanpa adanya tubuh kasar yang ditempati. Dengan bersatunya antara jasmani dan rohani ini maka terbentuklah kepribadian manusia. Sebagai makhluk yang sempurna dari semua makhluk Tuhan, tentunya mempunyai tujuan yang harus dicapai. Hal tersebut telah ditetapkan oleh Sang Pencipta dalam Q.S. al-Zariyat/51: 56:

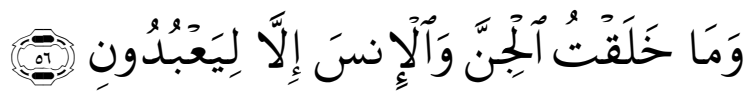

Terjemahnya:

Dan Aku tidak menciptakan jin dan manusia melainkan supaya mereka mengabdi kepada-Ku.

Dalam memenuhi tujuan hidup tersebut, ada yang menempuh jalan tasawuf untuk dengan mengurangi segala yang terkait dengan kehidupan dunia, untuk 
menghusukan ibadah kepada Allah swt, semata-mata, bahkan menolak hiasan dunia serta membenci perkara-perkara yang dapat memperdaya orang, menjauhi kelezatan harta benda dan kemegahan, senantiasa menyendirri menuju jalan Tuhan dengan berkhalwat dan beribadah, sehingga tercipta ketenangan ruhani dan kedamaian yang meruapakan dambaan setiap insan di dunia ini. Dengan menghususkan ibadah secara khusu kepada Allah swt. dan menjaga diri dari perbuatan dosa akan mengantarkan umat manusia mencapai kebahagiaan akhirat. Bagi seorang sufi, masuk syurga bukan tujuan dan kebahagiaan utama yang dinantikan, melainkan sebagai sarana dalam mencapai kebahagian sejati, yakni pertemuan dengan Kekasih Yang Maha Agung. Zat yang senantiasa dimintai pertolongan, Zat yang selalu menjaga dan memeliharanya, agar tidak masuk dalam perangkat hawa nafsu yang selalu menggoda, Zat yang selalu memberinya nikmat yang tidak terbatas. ${ }^{1}$ Keyakinan tentang melihat Allah swt. didasarkan pada Q.S. al-Qiyamah/75: 22-23.

Terjemahnya:

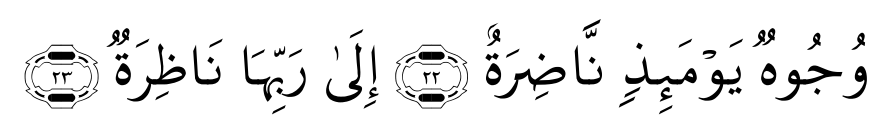

Wajah-wajah (orang-orang mukmin) pada hari itu berseri-seri. Kepada Tuhannyalah mereka melihat.

Walaupun hal tersebut diperoleh di hari kiamat, akan tetapi di dunia mereka sudah sudah merasakan secara batiniyah. Untuk merasakan bertemu dengan Tuham seorang sufi harus sampai pada puncak perjalan kerohanian yang ditempuhnya. Salah satu puncak perjalanan sufi adalah al-Ittihat.

\section{AL-ITTIHAD DALAM TASAWUF}

Al-ittihad yang diamalkan oleh al-Bustami adlaah suatu maqam yang tertinggi untuk lebih dekat kepada Allah, tapi sebelum sampai ke al-ittihad seorang sufi harus terlebih dahulu mengalami fana' dan baqa'.

Berbicara fana' dan baqa' sangat erat kaitannya dengan al-Itihad, yakni penyatuan batin atau rohani dengan Tuhan, karena tujuan dari fana' dan baqa' itu sendiri adalah ittihad itu. Mustafa Zuhri menyebutkan bahwa fana' dan baqa' tidak dapat dipisahkan dengan al-ittihad. ${ }^{2}$

Kata"fana" berarti: hancur, sirna, dan lenyap. ${ }^{3}$ Juga berarti keadaan dari sesuatu yang tidak berakhir. ${ }^{4}$

${ }^{1}$ Lihat Muhammad Musa Syarif, Kaifa Nuhibbullah wa Nasytaqu Ilaih, terj. Ahmad Yaman Syamsuddin, Quantum Cinta Bagaimana Melejitkan Kualitas Cinta Anda Kepada-Nya (Solo: Insan Kamil, 2008), h. 33.

${ }^{2}$ Lihat Musatafa Zuhri, Kunci Memahami Ilmu tasawuf (Cet. 1;Surabaya: Bina Ilmu 1985). H. 236.

${ }^{3}$ Ibrahm Anis, al-Muh'jam al-Washt, Jilid II (Cet. II, Kairo Dar al-Fikr, 1972), h. 704. 
Menurut kaum mutakallimin (para ahli teologi skolastik Islam) mengartikan yaitu: proses menghilangnya sifat sesuatu. ${ }^{5}$ Menurut kalangan sufi adalah hilangnnya kesadaran pribadi dengan dirinya sendiri atau dengan sesuatu yang lazim digunakan pada diri. Dengan kata lain tergantinya sifat-sifat kemanusiaan dengan sifat ketuhanan. ${ }^{6}$

Dalam hal itu, Mustafa Zuhri mengatakan bahwa yang dimaksud fana adalah lenyapnya inderawi atau kebasyariahan, yakni sifat sebagai manusia biasa yang suka pada syahwat dan hawa nafsu. Senantiasa diliputi sifat hakikat ketuhanan, sehingga tiada lagi melihat daripada alam baru, alam rupa atau dari alam wujud ini, maka dikatakan ia telah fana dari alam cipta atau dari alam makhluk. ${ }^{7}$

Sebagai akibat dari al-fana' adalah al-baqa' yang berarti terus menerus ${ }^{8}$ sebagai lawan dari al-Fana ia berarti tetap ada dan merupakan sifat wajib Tuhan.

Menurut teolog, bahwa hanya Allah yang baqa'. Dan tidak mengalami kehancuran (al-fana), melainkan kekal selamanya (al-baqa). Didasarkan firman Allah Q.S. al-Qasas/28: 88.

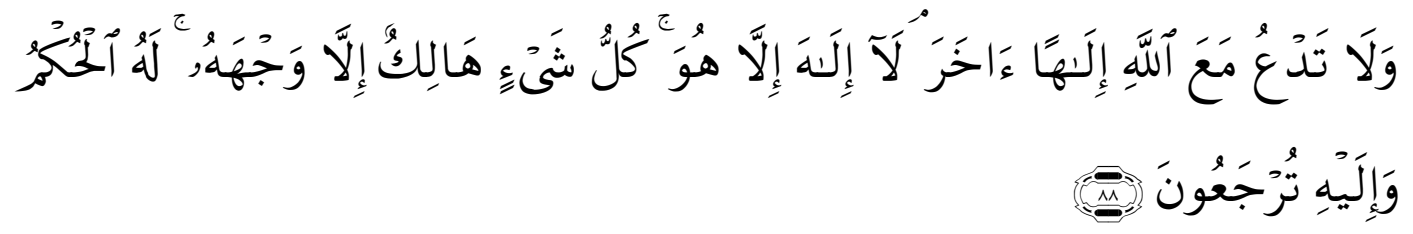

Terjemahnya:

Janganlah kamu sembah di samping (menyembah) Allah, Tuhan apapun yang lain. tidak ada Tuhan (yang berhak disembah) melainkan Dia. tiaptiap sesuatu pasti binasa, kecuali Allah. bagi-Nyalah segala penentuan, dan Hanya kepada-Nyalah kamu dikembalikan

Dari ayat di atas, dapat dipahami bahwa Allah saru-satuNya yang bersifat baqa' (ada selama-lamanya tanpa berkesudahan), sementara alam ciptaanNya bersifat fana' (akan hancur). Dilain ayat dipertegas lagi dalam Q.S. al-Rahman /55: 26-27.

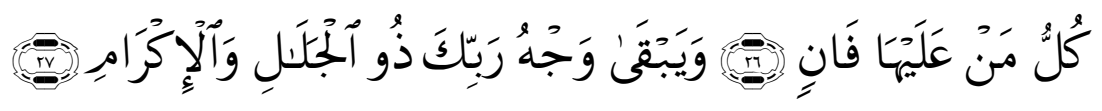

${ }^{4}$ Khan Sahb Khaja Khan, Tasawuf: Apa dan Bagaimana, terjemahan Achmad Nashr Budiman (Cet. I, Jakarta: PT Rsjs Grafindo Persada, 1995.), h. 83. Selanjutnya disebut "Khaja Khan"

h. 83 .

${ }^{5}$ Lihat Khaja Khan, Tasawuf: Apa dan Bagaimana, terjemahan Achmad Nashr Budiman

${ }^{6}$ Jamil Saliba, Mu'jam al-Falsafah, Jilid II (Beirut: Dar al-Kutb, 1979), h. 167.

${ }^{7}$ Mustafa Zuhri, Kunci Memahami Ilmu Tasawuf (Cet. 1;Surabaya: Bina Ilmu, 1985), h. 234.

${ }^{8}$ Abu Husain Ahmad Bin Faris Zakariyyah, Mu'jam Maqayis al-Lugah, Juz I, (Cet 2: Kairo: Mushtafa al-Bahyi al-Halaby, 1969), h. 276. 
Terjemahnya:

Semua yang ada di bumi itu akan binasa. Dan tetap kekal Dzat Tuhanmu yang mempunyai kebesaran dan kemuliaan.

Dalam ajaran tasawuf dipahami baqa sebagai kekalnya sifat-sifat terpuji, dan sifat-sifat Tuhan dalam diri manusia, karena lenyapnya sifat basyariyah, maka yang tetap adalah sifa-sifat Ilahiyah.

Fana' dan Baqa' merupakan dua hal yang tak dapat dipisahkan datang secara beriringan. Ibnu Qayyum menyebutkan bahwa al-Fana' dan al-Baqa' itu dua bentuk yang pada hakekatnya adalah satu. ${ }^{9}$ Dicontohkan Ibn al-Saraj al-Thusiy bahwa sifat kemanusiaan senantiasa ada sebagaimana warna hitam tidak hilam dari warna hitamnya dan warna putih tidak hilang dari warna putihnya, tetapi yang beruba dan hilang adalah sifat kemanusiaannya atau akhlaknya. ${ }^{10}$

Mengenai asal-usul pemikiran al-fana' ini terdapat beberapa versi, ada yang menyatakan berasal dari diluar agama Islam yaitu India melalui Persia masuk dalam Islam. $^{11}$ Ada pula yang menganggap sumbernya dari unsu-unsur kebudayaan luar Islam yang kemudian membentuk dirinya sendiri dalam Islam. ${ }^{12}$ Tapi yang jelas bahwa pemikiran tidak bertentangan dengan ajaran Islam sebenarnya.

Al-Jurjani memandang bahwa fana' itu dari aspek akhlak adalah gugurnya sifat-sifat tercela sebagaimana baqa' menunjukkan adanya sifat terpuji. Fana' itu terbagi kepada dua, yaitu: pertama, aspek akhlak yang diperoleh dengan memperbanyak riyadlah, dan kedua, tidak merasakan lagi adanya alam beserta segenap isinya, yaitu dengan tenggelam dalam keagungan Tuhan dan menyaksikan al-Haq. ${ }^{13}$

Lain halnya al-Sarraj, dia berpendapat fana' itu suatu keadaan yang membawa kekhususan yang positif bagi al-fana yang disebut al-baqa'. Fananya kebodohan adalah baqanya ilmu, fananya kemaksiatan adalah baqanya ketaatan, fananya kelalaian adalah baqanya ingatan, dan fananya penglihatan hamba adalah baqanya penglihatan inayat Allah. ${ }^{14}$

Jadi untuk sampai kepada ittihad, seorang sufi harus terlebih dahulu mengalami fana' 'an al-nafs, dalam arti kehancuran jiwa. Maksudnya adalah bukan hancurnya jiwa sufi menjadi tiada, tapi kehancurannya akan menimbulkan

\footnotetext{
${ }^{9}$ Ibrahm Basyuny, Nasy-at al-Tasawwuf al-Islami, (Mesir: Dar al-Ma'arif, t.th.), h. 238.

${ }^{10}$ Lihat Ibrahm Basyuny, Nasy-at al-Tasawwuf al-Islami, , h. 237.

${ }^{11}$ Lihat "Islam Indonesia", h. 273.

${ }^{12}$ Lihat "Islam Indonesia", h. 273

${ }^{13}$ Lihat Ibrahm Basyuniy Nasy-at al-Tasawwuf al-Islami, h. 238. Lihat pula Abu Bakar Muhammad bin Ishaq al-Kalabadziy, al-Ta'aruruf fi Mazahb alhl al-Tasawuf, (Cet. BeirutLebanon: Dar al-Kutb al-'Ilmiyyah, 1433 H/1993 M.), h. 144-145.

14 Abu Bakar Muhammad bin Ishaq al-Kalabadziy, al-Ta'aruruf fi Mazahb alhl al-
} Tasawuf, h. 144-145 
kesadaran sufi terhadap dirinya inilah yang disebut kaum sufi al-fana' 'an al-nafs wa al-baqa' bi 'ilah, dengan arti kesadaran tentang diri sendiri hancur dan timbullah kesadaran diri Tuhan. ${ }^{15}$ Maka disinilah seorang sufi terjadi persatuan dengan Tuhannya (ittihad), sehingga seorang sufi mengeluarkan kaa-kata dari mulutnya yang tidak disadari yaitu: "Aku adalah Tuhan".

Abu Yazid al-Bustami memandang bahwa fana dan baqa itu adalah hancurnya perasaan kesadaran akan adanya tubuh kasar manusia, kesadarannya bersatu dalam iradah Tuhan, tidak menyatu dengan Tuhan. Persoalannya adalah bagaimana Abu Yazid al-Bustami sampai kesana? Ia pernah bermimpi bertemu dengan Tuhan dan aku bertanya:"Ya Tuhanku bagaimana cara untuk sampai kepada Engkau? Tuhan menjawab "Tinggalkan dirimu dan datanglah". ${ }^{16}$ Sufi untuk masuk dalam dunia fana', maka ada empat hal yang harus diperhatikan yang merupakan juziyyat(bagian-bagian) dari fana ${ }^{, 17}$ yaitu:

\section{1) Al-Sukr}

Al-Sukkar didahului oleh fase Ghaibah yaitu suatu keadaan pertengahan antara hubb dan fana'. Al-Sukkar tidak bisa dicapai kecuali orang yang dalam keadaan "mencintai" ( "mawajid"), ketika itu seorang hamba dibukakan sifat-sifat keindahan sehingga al-sukr itu tercapai yang ditandai dengan hati berdebar dari hati berdebar dan hati yang penuh rasa cinta terhadap Tuhan. ${ }^{18}$ Contoh ketika alBustami dalam keadaan al-Sukr dia mengeluarkan kata-kata dari mulutnya, Subehani ${ }^{19}$

\section{2) Al-Syathahat}

Dari segi bahasa adalah gerakan yaitu: gerakan rahasia dari orang yang sangat cinta, lalu mengeluarkan ungkapan-ungkapan yang aneh bagi pendengarnya, sehingga tidak ada orang yang dapat memahami ungkapan itu kecuali orang yang diberikan kemuliaan dan pemahaman yang luas. ${ }^{20}$ Contoh alBustami mengeluarkan ungkapan-ungkapan yang aneh: "Manusia tobat dari dosanya, tetapi aku tidak. Aku hanya mengucapkan tiada Tuhan selain Allah, Abu Yazid tobat dengan syahadat, karena lafadz itu menggambarkan Tuhan masih jauh dari sufi dan berada dibelakang tabir, Abu Yazid ingin berada dihadhirat Ilahi, berhadapan langsung dengan Tuhan dan mengatakan kepadaNya: "Tidak ada

${ }^{15}$ Lihat Harun Nasution, Tasawuf, dalam Budh Munawra Rachman (ed.), Kontektualisasi Doktrin Islam Dalam Sejarah, (Cet. I, Jakarta: Yayasan Wakaf Paramadina, 1994), h. 171.

${ }^{16}$ Lihat Harun Nasution, Tasawuf, dalam Budh Munawra Rachman (ed.), Kontektualisasi Doktrin Islam Dalam Sejarah, h. 171

17 Lihat selengkapnya Ibn Qayyim al-Jauziyah, Raudah al-Muhbbin wa Nuzhat alMusytaqin, Beirut: Dar al-Kutub al-'Ilmiyyah, 1995, h.., 240-264.

${ }^{18}$ Lihat Ibn Qayyim al-Jauziyah, Raudah al-Muhbbin wa Nuzhat al-Musytaqin, h. 264.

${ }^{19}$ Lihat Ibn Qayyim al-Jauziyah, Raudah al-Muhbbin wa Nuzhat al-Musytaqin,, h. 244.

${ }^{20}$ Ibn Qayyim al-Jauziyah, Raudah al-Muhbbin wa Nuzhat al-Musytaqin, h. 246. 
Tuhan selain Engkau”. Jadi dengan kecintaannya itu, Abu Yazid berkata: “Aku tidak meminta dari Tuhan selain Tuhan'. ${ }^{21}$ Dari pernyataan di atas, nampaknya alBustami sudah dekat dengan Tuhan, namun persatuan (ittihad) denganNya belum terjadi dengan sempurna.

\section{3) Zawal al-Hujab}

Zawal al-hijab adalah suatu keadaan seorang sufi tidak ada lagi yang diinginkan kecuali Allah, seperti halnya denga al-Hallaj ketika sudah mencapai kenikmatan bertemu dengan Tuhannya, dia berkata: Aku ingi Engkau, aku tidak ingin dari Engkau suatu balasan, akan tetapi aku inginkan dari Engkau adalah siksaan. $^{22}$

Hal ini juga terjadi pada diri Rabi'ah al-Adawiyyah dengan mahabbahnya dengan ungkapan: "Aku mengabdi kepada Tuhan bukan karena takut kepada neraka, bukan pula karena ingin masuk surga, tetapi aku mengabdi karena cintaku kepadaNya. Ia bermunajat: "Tuhanku, jika kupuja Engkau karena takut kepada neraka, bakarlah mataku kare Engkau, janganlah sembunyikan keindahanMu yang itu dari pandanganku. ${ }^{23}$ Dia beribadah bukan karena takut kepada Allah, bukan pula mengharapkan surga, tapi hanya karena cintanya kepada Tuhan.

Dalam pada itu al-Bustami menyatakan sebagai berikut: Ketika ditanya tentang surga, dia menjawab: "Surga itu adalah permainan anak-anak". Karena surga baginya adalah hijab yang paing besar, sesungguhnya penduduk surga itu tinggal di dalam surga, sementara setiap orang berada dalam surga bererti berdiam kepada selain Tuhan, dengan demikian dia mahjub. ${ }^{24}$

\section{4) Ghalbat al-Syuhud}

Ini merupakan tempat di atas tempat, dan waktu diatas waktu, disini tidak lagi menanyakan kenapa dan bagaimana. Hal ini terjadi ketika perasaan, kesadaran dan penyaksian seorang sufi sampai kepada puncak fana', lalu dia lupa dirinya dan tidak ada selain Allah, sekiranya ditanya: dari mana? Dan hendak kemaan? Tidak ada jawaban kecuali "Allah". ${ }^{25}$

Dengan demikian, pada tingkat terakhir ini, sudah sampai kepada tingkat terakhir dari proses fana', sehingga sampailah kepada persatuan (ittihad0 dengan Tuhan yaitu dimana seorang sufi telah bersatu dengan Tuhan, yang menyatakan persatuan antara yang mencintai dengan yang dicintai. Dengan demikian keluarlah ungkapan-ungkapan yang aneh seperti; subehani, subehani.

\footnotetext{
${ }^{21}$ Lihat Harun Nasution "Tasawuf, dalam Budh Munawra Rachman (ed.), Kontektualisasi Doktrin Islam Dalam Sejarah, h. 172.

${ }^{22}$ Ibn Qayyim al-Jauziyah, Raudah al-Muhbbin wa Nuzhat al-Musytaqin, h. 248.

23 Lihat Harun Nasution, "Tasawuf” dalam Budh Munawra Rachman (ed.), Kontektualisasi Doktrin Islam Dalam Sejarah, h. 168.

${ }^{24}$ Lihat Ibn Qayyim al-Jauziyah, Raudah al-Muhbbin wa Nuzhat al-Musytaqin, h. 248.

${ }^{25}$ Ibn Qayyim al-Jauziyah, Raudah al-Muhbbin wa Nuzhat al-Musytaqin, h. 257.
} 
Ungkapan di atas, menggambarkan bagaimana Tuhan hadir dalam diri Abu Yazud dengan wahdaniyyat, anniyat, dan abadiyatNya, sehingga seseorang ingin melihat Tuhan cukup hanya memandang al-Bustami dengan permintaannya untuk dihiasi dengan permintaannya dikabulkan, maka terjadilah persatuan, sebagai terungkap dalam kata-kata berikut: "Abu Yazid, semuanya kecualai engkau adalah makhlukKu". Akupun berkata aku adalah Engkau, Engkau adalah aku dan aku adlah Engkau.

Dalam literatur disebutkan bahwa dalam ittihad, yang satu memanggil yang lain dengan kata-kata: hai Aku. Hal ini terjadi pada Abu Yazid, seperti ungkapannya ketika terjadi ittihad, maka Ia pun berkata kepadaku, "hai Engkau, aku menjawab melalui diriNya "Hai Aku". Ia berkata kepadaku "Engkaulah Yang Satu". Aku menjawab "Akulah Yang Satu". Ia berkata lagi, "Engkau adalah Engkau". Aku menjawab, "Aku adalah Aku". ${ }^{26}$

Dalam ungkapan di atas adalah kata-kata Abu Yazid "Aku menjawab melalui diriNya" dengan kata-kat "melalu diriNya" menggambarkan berstaunya Abu Yazid dengan Tuhan, jiwanya melebur dalam dir Tuhan. Ia tidak ada lagi selain Tuhan, jadi yang mengatakan "Hai Aku Yang Satu” bukanlah Abu Yazid, tetapi Tuhan melalui lidah Abu Yazid.

Dalam tasawuf, kata-kata yang keluar dari mulut seorang sufi, bukanlah ungkapan yang sebenarnya diucapkan oleh sufi (sebagaimana dipahami oleh orang awam), tapi karena dia dalam keadaan mabuk dan fana, sehingga ucapan-ucapan itu, yang sebenarnya tidak mengakui dirinya sebagai Tuhan, seperti halnya katakata Abu Yazid di atas, dia tidak mengakui dirinya sebagai Tuhan.

Namun demikian, ungkaan-ungkapan yang keluar dari mulut sufi itu, menimbulkan berbagai tanggapan antara pro dan kontra dikalangan umat Islam, bukan hanya pada dataran orang awam bahkan pada tingkat intelektual, misalnya Ibn Salim menganggap sebagai "kafir". 27 Bagi orang yang bersikap toleran terhadap ajaran ittihad ini memandang hanya sebagai penyelewengan (inhiraf). ${ }^{28}$ Yang jelas bahwa Abu Yazid al-Bustami adalah sufi yang sudah sampai pada tingkat yang lebih tinggi, sehingga dapat bersatu dengan Tuhan seacara batiniah melalui fana sebagai langkah awal memasuki al-ittihad.

${ }^{26}$ Harun Nasution, Falsafat dan Mistisisme Dalam Islam (Jakarta: Bulan Bintang, 1973), h. 85 .

${ }^{27}$ Lihat Abd. Kadir Mahmud, Qadiyat al-Tasawwuf (Kairo: Dar al-Ma'arif, t.th.), h. 315.

${ }^{28}$ Abuddin Nata, Akhlak Tasawuf (Cet. I, Jakarta: PT Raja Grafindo, 1996). H. 237. 


\section{TOKOHNYA}

Al-Bustami ${ }^{29}$ nama lengkapnya adalah Abu Yazid Thaifur bin 'Isa bin Surusyan $^{30}$ al-Bustami. ${ }^{31}$ Ia dilahirkan di Bistam, salah satu kota di daerah Qumis ${ }^{32}$ Persia tahun 188 H./804 M. Ayahnya (Isa) adalah salah seorang tokoh di Bistam, sedangkan ibunya adalah seorang yang taat dan bersifat zuhud. Ia dibesarkan dalam keluarga yang taat beragama. Pada masa mudanya ia mempelajari al-Qur'an bahkan mendalaminya dan belajar hadis Nabi serta ilmu fikih mazhab Hanafy. ${ }^{33}$ Jadi disamping seorang sufi, ia tetap menjungjung tinggi hukum syariat serta sangat cinta terhadap ilmu kalam. Tidak didapat informasi bahwa ia menulis buku sebagaimana dengan tokoh-tokoh lainnya. Ajaran-ajaran beliau dari pandanganpandangannya hanya bias ditemukan melalui catatan-catatan dari muridnya atau tokoh-tokoh yang pernah bertemu dengannya. ${ }^{34}$

Jadi, al-Bustami dikenal sebagai salah seorang imam terkenal dalam ilmu tasawuf, sehingga ia dikagumi oleh tokoh-tokoh lainnya, dikatakan oleh al-Junaid: "Syeikh paling tinggi maqamnya dan kemuliaannya serta kedudukannya diantara sufi yang lainnya seperti kedudukan Jibril diantara para Malaikat yang lainnya.

Pengalaman-pengalaman al-Bustami dalam bidang kesufian dan ucapanucapannya terkadang sulit dipahami oleh orang awam, sehingga sebagian ulama ada yang menentangnya dan membenci beliau bahkan menganggap menyimpang dari ajaran agama Islam yang sebenarnya, seperti ungkapan beliau: Tidak ada Tuhan selain Aku, maka sembahlah Aku", menyebabkan beliau sering mengasingkan diri. Dalam pengasingan diri itulah beliau wafat pada tahun 261 H./875 M. ${ }^{35}$ di Bistam.

${ }^{29}$ Harun Nasution menyebutkan dalam bukunya "Mistisme" dengan penyebutan alBustami. Lihat Abuddin Nata, Akhlak Tasawuf, h. 80. Sementara kalangan orientalis menyebutkan dengan nama Bayazid.

${ }^{30}$ Surusyan adalah nenek al-Bustami seorang Majusi kemudian memeluk agama islam, lihat Jamal al-Din Abi al-Faraj ibn al-Jauzy, Shfat al-Shafwah, Juz VI (Cet. I; Beirut-Lebanon: Dar al-Kutub al'Ilmiyyah, 1989 M./1409 H.), h. 98. Ada pula mengatakan bahwa dia sebelumnya memeluk agama Zoroaster lihat H. R. Gibb, Shorter Encyclopedia of Islam (London: Luzac \& Co, 1961), h. 63.

${ }^{31}$ Abu Yazi al-Bustami mempunyai dua saudara yang hampir sama yaitu Adam alBustami dan 'Ali al-Bustami dan keduanya termasuk orang sufi. Lihat H. R. Gibb, Shorter Encyclopedia of Islam, h. 63.

${ }^{32}$ Daerah itu terletak di jalur perjalanan menuju Nasabur, masuk dalam daerah kekuasaan Islam pada masa pemerintahanKhalifah Umar bin al-Khattab tahun $81 \mathrm{H}$. Lihat Abd al-Kadir Mahmud, Al-Falsafah al-Shufiyyag fi al-Islam (t. tp: Dar al-Fikr al'Arabi, 1966), h. 309.

33 Adapula yang menyatakan bahwa ia bermazhab Ja'fariy, karena Abu Ja'far al-Shadiq adalah gurunya dan termasuk Imam Mustafa al-Mubarak.

${ }^{34}$ Lihat Abd al-Kadir Mahmud, Al-Falsafah al-Shufiyyag fi al-Islam (t. tp: Dar al-Fikr al'Arabi, 1966), h. 309.

${ }^{35}$ Lihat Harun Nasution Falsafat dan Mistisisme Dalam Islam, h. 81 


\section{KESIMPULAN}

Al-Ittihad merupakan salah satu ajaran tasawuf yang dibawa oleh Abu Yazid Thaifur bin 'Isa bin Surusyan al-Bustami. Seorang sufi yang berada pada tingkat al-Ittihad merasa dirinya bersatu dengan tuhan, satu tingkatan yang menunjukkan bahwa yang mencintai dan yang dicintai telah menjadi satu, sehinggga salah satu dari mereka dapat memanggil yang satu lagi dengan katakata, "Hai aku. Al-Ittihad dicapai dengan melalui fana dan baqa. Fana merupakan hancurnya perasaan kesadaran akan adanya tubuh kasar manusia, menyatu dengan Tuhan. Kesadaran bersatu dalam iradah Tuhan, bersifat menetap sehingga lahirlah ucapan-ucapan tertentu seperti Subehani. Untuk itu sebelum memasuki tahap fana seorang sufi harus memperhatikan 4 hal yaitu;

1. Al-Sukr yaitu keadaan antara cinta dengan fana.

2. Al-Syathahat adalah ungkapan-ungkapan aneh yang dikeluarkan oleh sufi

3. Zawal al-Hujab adalah keadaan sufi yang tidak menginginkan lagi sesuati kecuali Allah

4. Ghalbat al-Syhud; keadaan seorang sufi baik dari segi perasaan, kesadaran dan penyaksian sampai kepada puncak fana', lalu dia lupa dirinya dan tidak ada selain Allah.

\section{DAFTAR PUSTAKA}

Basyuni, Ibrahm, Nasyat al-Tasawwuf al-Islam, Mesir: Dar al-Nahdat al-'Arabi, 1979.

H.A.R.Gibb and J.H.Krammers, Shorter Encyclopedia of Islam, London: Luzcac \& Co., t.th.

Ibn Qayyim al-Jauziyah, Raudah al-Muhbbin wa Nuzhat al-Musytaqin, Beirut: Dar al-Kutub al-'Ilmiyyah, 1995.

, Madarij Salikin Bain Manazil Iyyaka Na'budu wa Iyyaka Nasta'in, jilid II Beirut: Dar al-Fikr, 1408 H.

Ibnu Faris, Abi al-Husain Ahmad ibn Zakariyah, Mu'jam al-Maqayis al-Lugah, Beirut: Dar al-Fikr,1991.

Jauzy, Jamal al-Din Abi al-Faraj ibn al-Jauzy, Shfat al-Shafwah, Juz VI, Cet. I; Beirut-Lebanon: Dar al-Kutub al'Ilmiyyah, 1989 M./1409 H.

Al-Kalabazi, Abu Bakar Muhammad, al-Ta'aruf li Mazhab ahl al-Tazawwuf, Kairo: Maktabat al-Kulliyyah, 1969.

Khan Sahb Khaja, Tasawuf: Apa dan Bagaimana, Jakarta: PT Rsjs Grafindo Persada, 1995.

Mahmud, Abd Kadir Mahmud, Al-Falsafat al-Shufiyyah Fi al-Islam, Kairo: Dar al-Fikr al-Arabi, 1966. 
Mahmud, Abdul Halim, Qadiyah al-Tasawuf al-Munqiz min al-Dalal, terj. Abu Bakar Basymeleh Hal Ihwal Tasawuf, T.tp.: Dar al-Ihya', t.th.

Nasution, Harun, dalam Budi Munawar Rachman (editor), Kontektualisasi Doktrin Islam Dalam Sejarah, Jakarta: Paramadina, 1995. , Falsafat dan Mistisisme Dalam Islam, Jakarta: Bulan Bintang, 1973.

Nata, Abuddin, Akhlak Tasawuf, Cet. I, Jakarta: PT Raja Grafindo, 1996.

Zahri, Mustafa, Kunci Memahami Ilmu tasawuf, Cet. 1;Surabaya: Bina Ilmu 1985. 